\title{
QUATERNARY INTERGLACIAL SEDIMENTS AS POSSIBLE NATURAL SOURCES OF ARSENIC AND MOLYBDENUM ANOMALIES IN STREAM SEDIMENTS IN LITHUANIA
}

\author{
Rimantė ZINKUTĖ, Valentinas BALTRŪNAS, Ričardas TARAŠKEVIČIUS, Bronislavas KARMAZA, \\ Rimutė STAKĖNIENĖ, Vaida ŠEIRIENĖ, Dalia KISIELIENĖ
}

Nature Research Centre Institute of Geology and Geography, T. Ševčenkos g. 13, 03223 Vilnius, Lithuania

Submitted 16 Sept. 2013; accepted 19 May 2014

\begin{abstract}
Geochemical investigations were conducted on Quaternary interglacial sediments in order to reveal if they can be a natural source of 10 potentially harmful chemical elements: $\mathrm{As}, \mathrm{Ba}, \mathrm{Cr}, \mathrm{Cu}, \mathrm{Mn}, \mathrm{Mo}, \mathrm{Ni}, \mathrm{Pb}, \mathrm{V}$ and $\mathrm{Zn}$. Determination of the total contents of elements in 680 samples was performed by EDXRF analysis. The content of $\mathrm{Ni}$, $\mathrm{Cu}, \mathrm{Pb}, \mathrm{Ba}$ in all analysed samples was lower than maximum permissible concentrations (MPC) for soil, the content of $\mathrm{Zn}, \mathrm{V}, \mathrm{Cr}$, Mn exceeded MPC values only in several samples $(\leq 4 \%)$. The highest percentage of anomalous samples where MPC was exceeded was characteristic of Mo (21\%) and As (12.6\%). Therefore, interglacial sediments, especially enriched in organic matter and other sorbents, comprise one of the possible natural sources of Mo and As. It is probable that they contribute to As and Mo anomalies in stream sediments in Lithuania.
\end{abstract}

Keywords: natural sources, interglacial sediments, arsenic, molybdenum, total organic carbon, total inorganic carbon, iron.

\section{Introduction}

Elevated contents of harmful chemical elements can originate not only from anthropogenic activity, but also from natural sources (Nagajyoti et al. 2010). Volcanoes (Ernst 2012; Ayris, Delmelle 2012; Calvo et al. 2013) and forest fires (Pereira, Ubeda 2010) are the main natural sources of air pollution. Leaching from deposits is the main natural source of groundwater and surface water pollution (Falk et al. 2006; Baba, Tayfur 2011). Ore deposits are the most obvious natural sources of harmful chemical elements (Von der Heyden, New 2004).

In Lithuania insufficient attention has been paid to various possible natural sources of anomalies of harmful chemical elements, because the main part of geochemical investigations has been concentrated in urban territories or near, where anthropogenic sources are abundant (Vasarevičius et al. 2010; Taraškevičius, Zinkute 2011; Kumpienè et al. 2011; Pundyte et al. 2011; Stakènienè et al. 2011; Zinkute et al. 2011; Galkus et al. 2012). Research was done also on military grounds (Vasarevičius, Greičiūtè 2004; Idzelis et al. 2006), landfills (Jaskelevičius, Lynikienè 2009) or near highways (Butkus, Šalčiūnienè 2011). The focus on urban areas is understandable, because of their high heavy metal fluxes (Milukaite et al. 2008). Elevated contents of harmful chemical elements in topsoil of the country also often have been explained by anthropogenic reasons (e.g. the influence of distant pollution sources or diffuse pollution by agriculture). The influence of forest fires in Lithuania, which can be both natural and anthropogenic, has also been analysed and slight increases of $\mathrm{Cd}$, $\mathrm{Cr}, \mathrm{Cu}, \mathrm{Mn}, \mathrm{Zn}$ and $\mathrm{Fe}$ in the mineral topsoil of Scots pine forests has been found (Marozas et al. 2013). Growth of $\mathrm{Cu}, \mathrm{Pb}, \mathrm{Zn}$ in stream water has been correlated with land fires (Ignatavičius et al. 2006).

Natural geochemical anomalies have been analysed only in surface sediments of the country (i.e. topsoil and stream sediments) (Kadūnas et al. 1999). From natural reasons, the unequal amount of soil clayey component has been often mentioned in Lithuania (Kadūnas et al. 1999). It depends on different origin or age of soil parent materials. Soil of most regions of the country is less weathered and contains higher contents of most chemical elements than soil of Ašmena-Medininkai Heights (Kadūnas et al. 1999). The latter is $\sim 10000$ years older and was formed

Corresponding author: Rimante Zinkute

E-mail: zinkute@geo.lt 
on glaciogenic deposits of the Medininkai glaciation of Middle Pleistocene. Similar explanations have been given for elevated contents of harmful chemical elements in stream sediments.

Stream sediments are not only influenced by surface run-off, but also by groundwater discharge (Lachmar et al. 2006). So part of the content of chemical elements can be leached from underlying layers. Parent material or rock outcrops comprise the most important natural source of heavy metals; besides, the contents of the elements depend on both rock type and environmental conditions activating their weathering (Nagajyoti et al. 2010). So search for rock outcrops with elevated concentrations of harmful chemical elements is very important, especially in Lithuania where there is lack of geochemical analysis of upper Quaternary sediments. Part of these sediments may be potential sources of anomalies in stream sediments.

Pre-Quaternary sedimentary rocks in Lithuania are covered by a thick Quaternary cover: average thickness is $130 \mathrm{~m}$ (Kadūnas et al. 1999) with increased thickness in palaeo-incisions of the sub-Quaternary surface (Baltrūnas, Gaigalas 2004). Subdivision of the Quaternary is based on climate, i.e. glacials and interglacials. Lithuanian Quaternary sediments were formed during seven sedimentary cycles (Fig. 1): Daumantai pre-glacial, Kalviai glacial and Vindžiūnai interglacial, Dzūkija glacial and Turgeliai interglacial, Dainava glacial and Butenai interglacial, Žemaitija glacial and Snaigupèlè interglacial, Medininkai glacial and Merkinè interglacial, Nemunas glacial (with Grūda and Baltija stages) and the Holocene (Kondratienè 1996; Baltrūnas et al. 2013a).

The greatest number of the Pleistocene global coolings and warmings is recorded in Poland, Belarus and

\begin{tabular}{|c|c|c|}
\hline 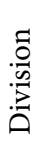 & 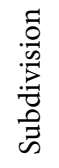 & Step formation \\
\hline \multirow{3}{*}{ 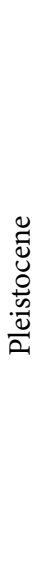 } & $\frac{\bar{\varpi}}{\tilde{a}^{\prime}}$ & $\begin{array}{l}\text { Nemunas (Weichselian), glacial } \\
\text { Merkinè (Eemian), interglacial }\end{array}$ \\
\hline & $\frac{\stackrel{0}{0}}{\stackrel{\nabla}{*}}$ & $\begin{array}{l}\text { Medininkai (Warthe), glacial } \\
\text { Snaigupèlè (Karlich), interglacial } \\
\text { Žemaitija (Drenthe), glacial } \\
\text { Butènai (Holsteinian), interglacial } \\
\text { Dainava (Elsterian 2), glacial } \\
\text { Turgeliai (Voigstedt), interglacial } \\
\text { Dzūkija (Elsterian 1), glacial } \\
\text { Vindžiūnai (Bavelian), interglacial } \\
\text { Kalviai (Nidanian), glacial }\end{array}$ \\
\hline & 岕 & Daumantai complex (preglacial) \\
\hline
\end{tabular}

Fig. 1. Quaternary stratigraphic scheme of Lithuania
Ukraine (Lindner et al. 2004). Thus, correlation of Pleistocene deposits in Poland and in neighbouring countries is very important (Ber 2006; Lindner et al. 2006). Some interglacial sediments are composite with interglacialrank warmings separated by non-glacial coolings (Lindner et al. 2013). Investigations of Quaternary interglacial sediments started in Lithuania, and the geochemical database was compiled in 2012 and anomalous contents of some harmful chemical elements were revealed (Baltrūnas et al. 2013b).

Quaternary interglacial sediments were chosen as the study object in the search for possible natural sources of harmful chemical elements, due to several reasons: 1) they have undoubtfully natural origin; 2) they were usually formed in palaeolakes where high accumulations of most chemical elements (including potentially harmful) with fine clay particles, often with increased content of organic matter were possible; 3 ) the outcrops of these sediments are usually on the banks of streams, so during flood events harmful chemical elements can be washed out and migrate downstream causing natural anomalies in stream sediments. Of course, the real possibility of migration of harmful chemical elements from interglacial Quaternary sediments to contemporary stream sediments is not analysed here.

The aim of this research is to demonstrate that there are many more samples with anomalous contents of As and Mo compared with the other harmful chemical elements $\mathrm{Ba}, \mathrm{Cr}, \mathrm{Cu}, \mathrm{Mn}, \mathrm{Ni}, \mathrm{Pb}, \mathrm{V}$ and $\mathrm{Zn}$ in Quaternary interglacial sediments and to give possible explanation of As and Mo enrichment in some intervals. The findings of this investigation might be useful for researchers of stream water and sediments, because As and Mo anomalies might be related to one of the factors affecting water quality in Lithuanian rivers (Gudas, Povilaitis 2013).

\section{Methods}

Samples of interglacial sediments were collected at five outcrops and four boreholes with the sampling interval of $5-10$ or $15-20 \mathrm{~cm}$. Vertical sections of Daumantai $(\mathrm{dm})$ preglacial, Vindžiūnai (vn), Turgeliai (tr) and Butènai (bt) interglacials are near Šventoji and Šlavè stream (Anykščiai District), of Snaigupèle interglacial (sn) on the bank of the Snaigupèle stream near Druskininkai, and of Merkinè interglacial (mr) on the bank of the River Nemunas (Varèna District) (Fig. 2).

Diatom analysis and plant macrofossil survey was performed in all sections. Respective methods are described in Baltrūnas et al. (2013c). Geochemical analysis was performed in the Nature Research Centre Institute of Geology and Geography. Energy-dispersive x-ray fluorescence equipment SPECTRO XEPOS with TurboQuant for pressed pellets calibration method was used for 
the determination of total contents of chemical elements in 680 samples. Sample preparation included air-drying, crushing and homogenization in agate mortar with agate pestle, then milling of sub-sample by MM 400 mixer mill with zirconium oxide grinding jars and balls and mixing with binder ( $4 \mathrm{~g}$ of material and $0.9 \mathrm{~g}$ of Licowax, dilution factor (DF) was 0.82).

Pressed pellets of $32 \mathrm{~mm}$ diameter were prepared by PP15 press. Quality control is assured by the participation of the laboratory in the "International Soil-analytical

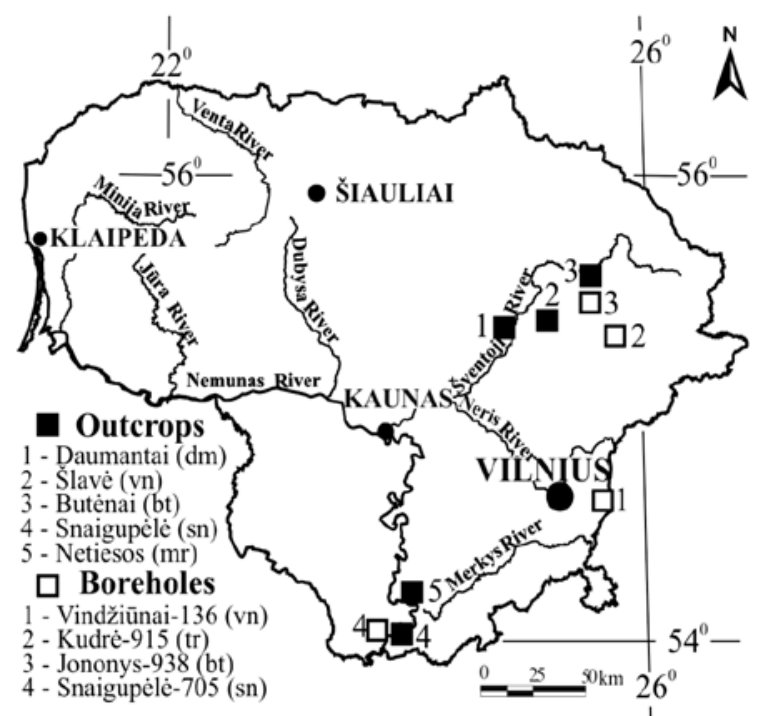

Fig. 2. Location of study objects of interglacial sediments

Notes: Interglacials: dm - Daumantai, vn - Vindžiūnai, tr Turgeliai, bt - Butènai, sn - Snaigupèlè, $\mathrm{mr}$ - Merkinė. Sampled depth intervals (in parentheses) of vertical sections: Daumantai (2.2-19.2 m), Vindžiūnai-136 (146-160 m), Šlavè (2.4-4.8 m), Kudrè-915 (75.8-91.8 m), Jononys-938 (20.2-39.2 m), Butènai (0.5-1.85 m), Snaigupèlè-705 (16.0-40.2 m), Snaigupėlè (4.65$6.20 \mathrm{~m})$, Netiesos $(4.05-17.3 \mathrm{~m})$.

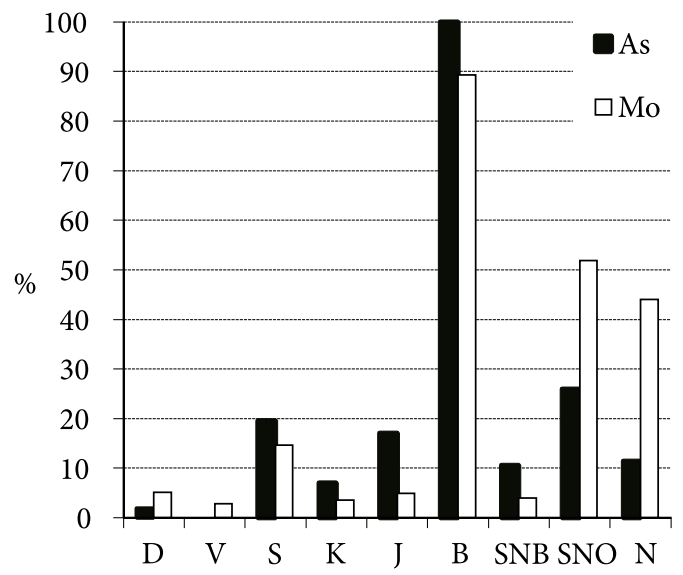

Fig. 3. Percentage of samples where MPC of As and Mo is exceeded in different sections. Outcrops: D - Daumantai, S Šlavè, B - Butėnai, SNO - Snaigupèlè, N - Netiesos. Boreholes: V - Vindžiūnai-136, K - Kudrè-915, J - Jononys-938, SNB Snaigupèlè-705
Exchange" (ISE) program of Wageningen Evaluating Programs for Analytical Laboratories (WEPAL) (Taraškevičius et al. 2013). ISE samples can be used for re-calibration. The contents of 10 harmful chemical elements As, $\mathrm{Ba}, \mathrm{Cr}, \mathrm{Cu}, \mathrm{Mn}, \mathrm{Mo}, \mathrm{Ni}, \mathrm{Pb}, \mathrm{V}, \mathrm{Zn}$ were compared with their maximum permitted concentrations (MPC) in soil (Taraškevičius et al. 2013).

Total carbon (TC) was determined in Šlavè, Vindžiūnai and Kudrè sections by elemental analyzer liquiTOC (Elementar analysensysteme $\mathrm{GmbH}$, Hanau-Germany). The procedure involves heating samples at $950{ }^{\circ} \mathrm{C}$ and measuring the combustion products by infrared energy detector with a precision of $\pm 1 \%$. The total organic carbon (TOC) was measured in the same way in carbonate-free subsamples, which were obtained by removing the carbonates with $\mathrm{HCl}$ and washing with deionized water. The difference between the two carbon measurements (TC-TOC) gives the total inorganic carbon (TIC) content. In part of the Netiesos section, the percentages of organic matter (OM) and total carbonates (TCB), calculated as $\mathrm{CaCO}_{3}$, were determined by loss on ignition (LOI) at $550{ }^{\circ} \mathrm{C}$ and $950^{\circ} \mathrm{C}$, respectively (Santisteban et al. 2004). The amount of inorganic non-carbonate minerals (NCM) was calculated as $100 \%-\mathrm{OM} \%-\mathrm{TCB} \%$. The main components of sediments (OM, TCB and NCM) were used for characterization of lithological units in the Netiesos section. The percentages of OM were recalculated to TOC, and TCB to TIC.

\section{Results}

The content of $\mathrm{Ni}, \mathrm{Cu}, \mathrm{Pb}, \mathrm{Ba}$ in all samples was lower than respective MPC (75 mg/kg for $\mathrm{Ni}, 100 \mathrm{mg} / \mathrm{kg}$ for $\mathrm{Cu}$ and $\mathrm{Pb}, 600 \mathrm{mg} / \mathrm{kg}$ for $\mathrm{Ba}$ ), indicating that interglacial sediments cannot be natural sources of these harmful chemical elements (Table 1). The contents of $\mathrm{Zn}, \mathrm{V}, \mathrm{Cr}$, Mn exceeded MPC values (300, 150, 100, $1500 \mathrm{mg} / \mathrm{kg}$ ) only in several samples and only in some sections. Such anomalous values comprise $\leq 4 \%$ from the total number of samples. The highest number of samples where element content exceeds MPC is characteristic of Mo and As. For Mo this comprises 21\% and for As $12.6 \%$ from the total number of samples. MPC of Mo $(5 \mathrm{mg} / \mathrm{kg})$ is exceeded in all sections and As $(10 \mathrm{mg} / \mathrm{kg})$ in almost all. Butenai, Snaigupèlè and Netiesos outcrop sections are most abundant in As and Mo anomalies (Fig. 3).

Butenai section (0.5-1.85 $\mathrm{m}$ ) has the highest percentage of anomalous samples: MPC of As is exceeded in all samples, of Mo in $89.3 \%$ of samples and of $\mathrm{Mn}$ in $42.9 \%$ of samples. There is also one sample where MPC of $\mathrm{Zn}$ is exceeded. The highest values of As, Mn, $\mathrm{Zn}$ are also in this section which consists of organogenic sediments. Snaigupèlè section (4.65-6.20 m) with organogenic sediments is also characterized by high percentages of Mo and As 
Table 1. Maximum content of harmful chemical elements $(\mathrm{mg} / \mathrm{kg})$ in sections of interglacial sediments compared with soil maximum permitted concentrations $(\mathrm{mg} / \mathrm{kg})$

\begin{tabular}{|c|c|c|c|c|c|c|c|c|c|c|}
\hline \multirow{2}{*}{$\begin{array}{l}\text { Ele- } \\
\text { ment }\end{array}$} & \multirow{2}{*}{ MPC } & $\mathrm{D}(156)$ & $S(41)$ & $\mathrm{V}(70)$ & $\mathrm{K}(57)$ & $\mathrm{J}(41)$ & $\mathrm{B}(28)$ & $\operatorname{SNB}(76)$ & $\mathrm{SNO}(27)$ & $\mathrm{N}(184)$ \\
\hline & & $\mathrm{dm}$ & vn & vn & $\operatorname{tr}$ & bt & bt & sn & sn & $\mathrm{mr}$ \\
\hline $\operatorname{As}(86)$ & 10 & $43.6(3)$ & $59.0(8)$ & 9.4 & $14.3(4)$ & $61.9(7)$ & $89.4(28)$ & $23.4(8)$ & $88.8(7)$ & $44.1(21)$ \\
\hline $\operatorname{Mo}(143)$ & 5 & $6.7(8)$ & $14.0(6)$ & $6.3(2)$ & $6.7(2)$ & $7.7(2)$ & $21.6(25)$ & $6.9(3)$ & $27.5(14)$ & $19.6(81)$ \\
\hline $\operatorname{Mn}(26)$ & 1500 & 137 & 249 & $1714(1)$ & $1686(1)$ & 2594(1) & $8847(12)$ & 2412(8) & 580 & 1589(3) \\
\hline $\operatorname{Cr}(5)$ & 100 & $103(1)$ & $152(2)$ & 78.0 & 74.5 & 69.3 & 71.2 & 84.2 & 72.4 & $392(2)$ \\
\hline $\mathrm{V}(3)$ & 150 & 101 & 209(3) & 100 & 85.4 & 80.9 & 60.5 & 115 & 88.6 & 92.9 \\
\hline $\mathrm{Zn}(1)$ & 300 & 56.4 & 119 & 54.0 & 70.4 & 198 & $303(1)$ & 189 & 174 & 211 \\
\hline $\mathrm{Ba}$ & 600 & 530 & 580 & 507 & 418 & 560 & 370 & 497 & 466 & 504 \\
\hline $\mathrm{Cu}$ & 100 & 19.5 & 52.6 & 22.3 & 38.7 & 21.7 & 48.7 & 26.1 & 22.6 & 24.2 \\
\hline $\mathrm{Ni}$ & 75 & 46.6 & 67.0 & 26.9 & 28.1 & 28.0 & 31.4 & 42.7 & 38.9 & 26.4 \\
\hline $\mathrm{Pb}$ & 100 & 17.0 & 20.0 & 19.0 & 15.8 & 19.6 & 18.0 & 19.6 & 16.3 & 16.2 \\
\hline
\end{tabular}

Notes: Interglacials: dm - Daumantai, vn - Vindžiūnai, tr - Turgeliai, bt - Butėnai, sn - Snaigupèle, mr - Merkinė. Outcrops: D - Daumantai, S - Şlavè, B - Butėnai, SNO - Snaigupèlè, N - Netiesos. Boreholes: V - Vindžiūnai-136, K - Kudrè-915, J - Jononys-938, SNB Snaigupele- 705 . Total number of samples analysed in each section is given in parentheses after abbreviation. The greatest maximum value in all 9 sections is in bold. Maximum content of element in the section is shaded if it exceeds MPC and the number of samples of the section where MPC is exceeded is given in parentheses. Total number of samples where MPC is exceeded is in parentheses after element. The table is based on TurboQuant for pressed pellets calibration method results.

anomalies: 51.9 and $25.9 \%$, respectively. Netiesos section $(4.05-17.3 \mathrm{~m})$ is on the third place with $44.0 \%$ of Mo and $11.4 \%$ of As anomalies (Fig. 3). Unlike Butenai and Snaigupèle, the lithology of the section is not uniform: the lowermost layer of silt is overlain by gyttja, the latter is covered by peat and the upper part consists of sand. Median content of As in gyttja is $9.7 \mathrm{mg} / \mathrm{kg}$, of Mo is $9.5 \mathrm{mg} / \mathrm{kg}$, and in the silt layer the respective median values are 8.7 and $7.4 \mathrm{mg} / \mathrm{kg}$. The re-calibrated (using ISE samples) median values of As and Mo in gyttja, silt and peat from Netiesos section exceed not only the respective median values in stream sediments of Lithuania, Šventoji and Middle Nemunas basin, but also the respective medians in different types of Lithuanian soil (Table 2). They are also higher than median values in European stream sediments and subsoil. In gyttja and silt, median values of As and Mo are especially high: they exceed respective median values in European topsoil and MPC of soil. Median content of Mo in gyttja, silt and peat is higher even than Mo maximum in Lithuanian stream sediments and Mo maximum in Lithuanian mineral soil. Median content of As in gyttja also exceeds As maximum in $\mathrm{Li}^{-}$ thuanian mineral soil and is close to As maximum in $\mathrm{Li}$ thuanian stream sediments.

In section of Snaigupèle outcrop the median recalibrated values of As and Mo also exceed median values in Lithuanian stream sediments. They are especially high in the Butenai section: re-calibrated As median is $59.7 \mathrm{mg} / \mathrm{kg}$, Mo is $7.93 \mathrm{mg} / \mathrm{kg}$.

All these facts confirm that interglacial Quaternary sediments comprise one of the possible natural sources of As and Mo anomalies. Netiesos section, which has been analysed in more detail by Baltrūnas et al. (2013c), can help to find out the peculiarities of layers enriched in As and Mo. The highest percentage of As anomalies is in gyttja layer ( $41.7 \%$ of its samples), it is followed by silt $(22.2 \%)$; the same lithological units are even more abundant in Mo anomalies: 100 and $97.2 \%$, respectively (Fig. 4).

Table 2. Arsenic and molybdenum contents $(\mathrm{mg} / \mathrm{kg})$ in interglacial sediments compared to soil and sediments

\begin{tabular}{|c|c|c|}
\hline Contents $(\mathrm{mg} / \mathrm{kg})$ & As & Mo \\
\hline Median in gyttja of Netiesos section & 11.1 & 9.23 \\
\hline Median in silt of Netiesos section & 10.2 & 7.24 \\
\hline Median in peat of Netiesos section & 6.59 & 5.06 \\
\hline MPC in soil $(1)^{*}$ & 10 & 5 \\
\hline Median in Lithuanian stream sediments $(2)^{*}$ & 3.0 & 0.8 \\
\hline Median in Middle Nemunas basin sediments $(2)^{\star}$ & 3.3 & 0.9 \\
\hline Median in Šventoji basin sediments $(2)^{*}$ & 2.9 & 0.7 \\
\hline Maximum in Lithuanian stream sediments $(2)^{\star}$ & 11.7 & 4.95 \\
\hline Median in sandy soil of Lithuania $(2)^{\star}$ & 1.8 & 0.62 \\
\hline Median in sandy loamy soil of Lithuania $(2)^{*}$ & 2.9 & 0.67 \\
\hline Median in loamy soil of Lithuania $(2)^{\star}$ & 3.7 & 0.70 \\
\hline Median in organic soil of Lithuania $(2)^{*}$ & 1.7 & 0.68 \\
\hline Median in all soil types of Lithuania $(2)^{*}$ & 2.4 & 0.67 \\
\hline Maximum in mineral soil of Lithuania $(2)^{\star}$ & 7.9 & 2.55 \\
\hline Median in European topsoil $(3)^{*}$ & 7.03 & 0.62 \\
\hline Median in European subsoil $(3)^{\star}$ & 6.02 & 0.52 \\
\hline Median in European stream sediments $(3)^{\star}$ & 6.00 & 0.63 \\
\hline
\end{tabular}

*Sources: 1: Taraškevičius et al. (2013); 2: Kadūnas et al. (1999); 3: Salminen et al. (2005). 
Plant macrofossil and pollen analysis shows that they were formed during the Merkine (Eemian) interglacial climatic optimum when palaeoflora became most thermophilic. The intervals of increase of As and Mo correspond to two subzones of the thermal optimum. Comparison of median percentage of main components in four lithological units of Netiesos section reveals the differences among them (Fig. 5).

Sand unit predominantly consists of non-carbonate minerals (median NCM is $91.6 \%$ ), median value of carbonates is much lower $(\mathrm{TCB}=8.0 \%)$ and organic part $(\mathrm{OM})$ makes up only $\sim 0.4 \%$. In peat, the percentage of NCM is still the highest, but decreases to $50.0 \%$. Meanwhile OM increases to $36.7 \%$, the part of carbonates is the lowest (TCB $=2.6 \%)$. Both gyttja and silt have the highest part of

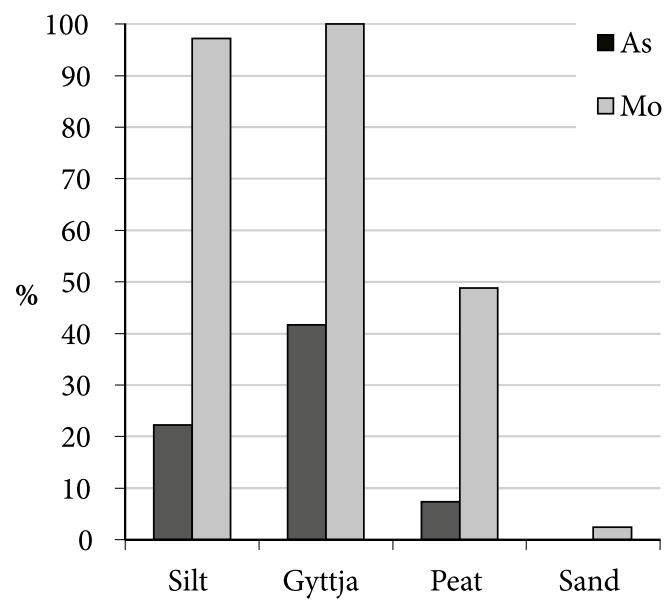

Fig. 4. Percentage of samples where MPC of As and Mo is exceeded in different layers of Netiesos section

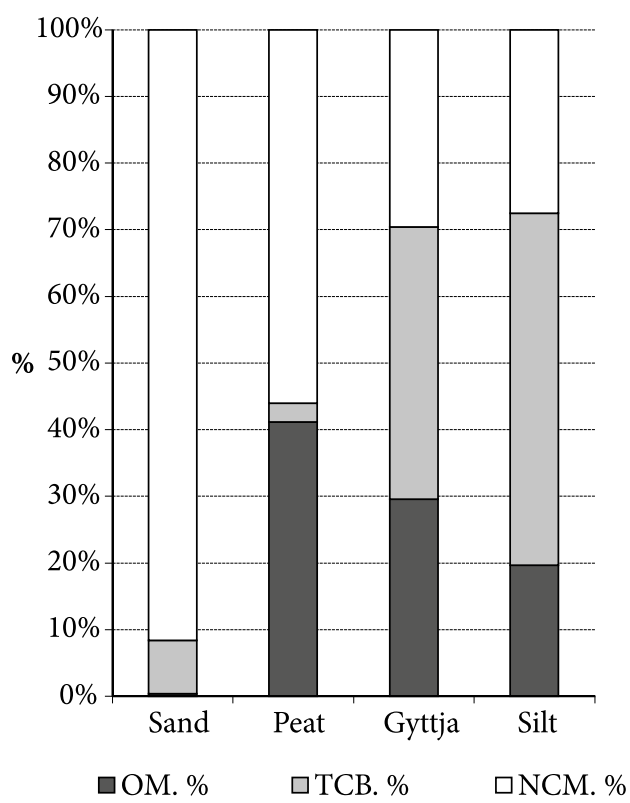

Fig. 5. Median percentage of main components in Netiesos. NCM: non-carbonate minerals, TCB: total carbonates, OM: organic matter carbonates (40.3\% and 51.7\%, respectively), but also high percentage of organics, especially gyttja $(\mathrm{OM}=29.2 \%)$. Meanwhile NCM percentage is much lower than in sand and peat. Elevated contents of As (Fig. 6b) and Mo (Fig. 6c) in the Netiesos section are obviously related to gyttja and silt, partly to peat where distribution pattern of main components shows higher percentage of organic matter and carbonates (Fig. 6a). The anomalies of both chemical elements are obviously not related to non-carbonate minerals: significant ( $\mathrm{p}<0.0001$, number of observations $n=70$ ) negative Pearson correlation coefficients of As $(r=-0.57)$ and Mo $(r=-0.78)$ with NCM confirm this statement. Since gyttja and silt are abundant in As and Mo anomalies and at the same time rich in carbonates and organics, the next task is to find out which of two components has more influence on the formation of the abovementioned anomalies.

In the Netiesos section, As and Mo have significant positive correlation both with TOC and with TIC. However, correlation of As is higher and more significant with TOC than with TIC, and correlation of Mo is higher with TIC than with TOC (Table 3).

Correlation of As and Mo with TOC and TIC has also been analysed in Šlavè outcrop and Kudrè-915 borehole sections. The percentage of As and Mo anomalies in these sections is lower than in Butenai, Snaigupéle and Netiesos sections (Fig. 3). Arsenic in both these sections has the strongest correlation coefficient with TOC compared to other chemical elements (including Mo); meanwhile its correlation with TIC is lower, as well as the significance level (Table 3). Molybdenum in Šlave section is significantly positively correlated both with TOC (higher p) and with TIC (lower p) (Table 3). As in the Netiesos section, the Mo correlation coefficient with TOC is lower than correlation of As with TOC. Meanwhile correlation of Mo with TIC is stronger than correlation of As with TIC. Although in Kudrè-915 section correlation of Mo with TOC and TIC is insignificant, the coefficient of Mo with TIC is positive, meanwhile with TOC it is negative. The above-mentioned correlations indicate that As anomalies are more related to OM and partly to carbonates, meanwhile Mo anomalies, on the contrary, are more related to carbonates than to OM.

Two dendrograms (Fig. 7a and b) were obtained for two different subsets of interglacial sediments: one of them included 86 samples with anomalous $(>10 \mathrm{mg} / \mathrm{kg})$ As contents, another one 143 samples with anomalous (>5 mg/kg) Mo contents. In both dendrograms As and Mo are in the same branch with eight other chemical elements: S, Br, Zn, Mn, Fe, P, Ca and Sr. These elements are proxies of organic matter $(\mathrm{S}, \mathrm{Br}, \mathrm{Zn})$, iron and manganese hydroxides ( $\mathrm{Fe}, \mathrm{Mn})$, carbonates $(\mathrm{Ca}, \mathrm{Sr})$ and phosphates $(\mathrm{P})$. Arsenic and molybdenum can be related to these components, most of which are good sorbents. 

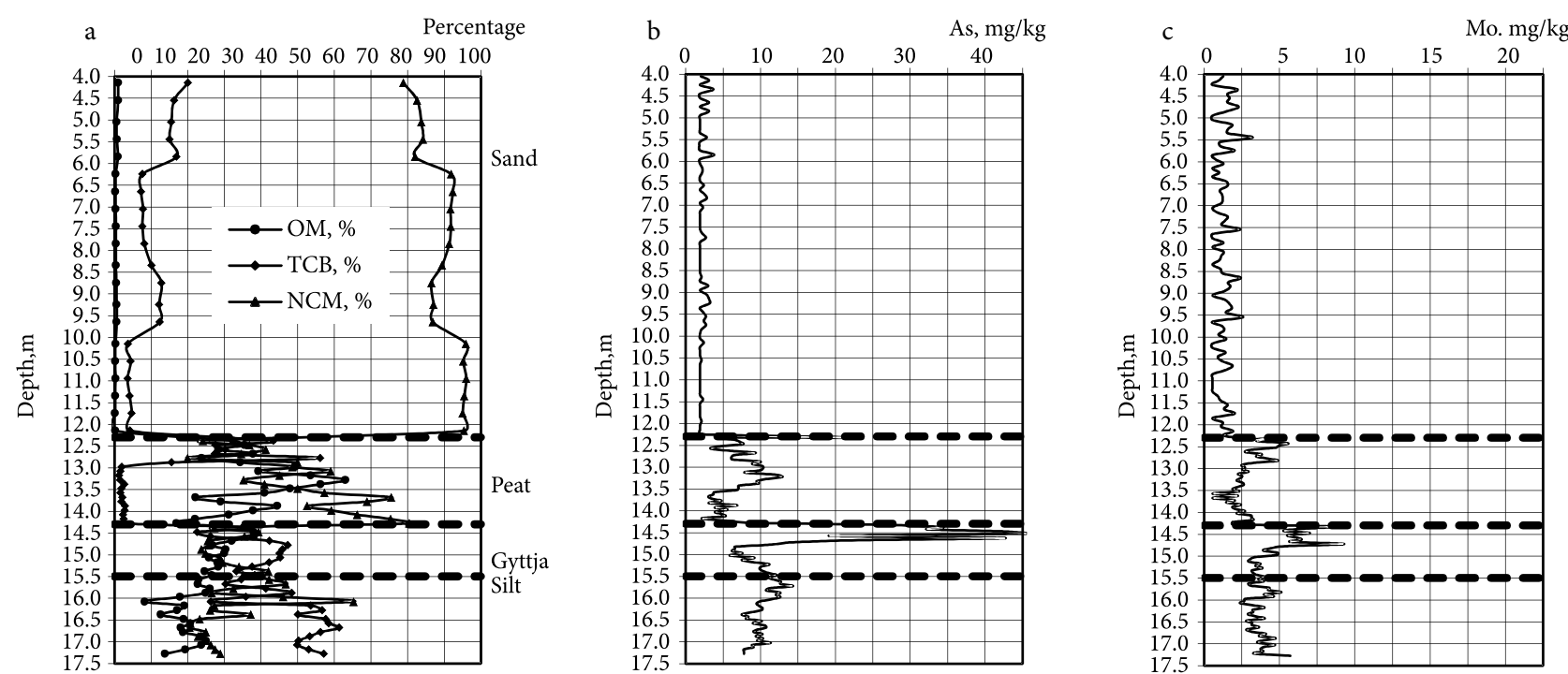

Fig. 6. Relationship of As and Mo to main components of palaeolake Netiesos sediments. NCM: non-carbonate minerals, TCB: total carbonates, OM: organic matter.

Table 3. Correlation of chemical elements with total organic carbon and total inorganic carbon in three sections

\begin{tabular}{|c|c|c|c|c|c|c|c|c|c|c|c|}
\hline \multicolumn{4}{|c|}{ Netiesos $(n=70)$} & \multicolumn{4}{|c|}{ Šlavè $(\mathrm{n}=41)$} & \multicolumn{4}{|c|}{ Kudrè-915 $(\mathrm{n}=57)$} \\
\hline $\mathrm{El}$ & $\mathrm{C}(\mathrm{TOC})$ & El & $\mathrm{C}(\mathrm{TIC})$ & $\mathrm{El}$ & $\mathrm{C}(\mathrm{TOC})$ & $\mathrm{El}$ & C(TIC) & $\mathrm{El}$ & $\mathrm{C}(\mathrm{TOC})$ & $\mathrm{El}$ & C(TIC) \\
\hline S & $0.834^{* * *}$ & $\mathrm{Ca}$ & $0.986^{* * *}$ & As & $0.974^{\star \star \star}$ & $\mathrm{Fe}$ & $0.472^{*}$ & As & $0.851^{\star * \star}$ & $\mathrm{Ca}$ & $0.547^{\star * *}$ \\
\hline $\mathrm{Cu}$ & $0.808^{\star * *}$ & $\mathrm{Sr}$ & $0.875^{\star * \star}$ & $\mathrm{Br}$ & $0.963^{\star * *}$ & Mo & $0.388 \mathrm{x}$ & S & $0.839^{\star * *}$ & $\mathrm{Br}$ & $0.510^{\star * \star}$ \\
\hline $\mathrm{Zn}$ & $0.748^{\star * *}$ & $\mathrm{Mn}$ & $0.772^{\star * *}$ & S & $0.917^{\star * *}$ & $\mathrm{~V}$ & $0.373 x$ & $\mathrm{Br}$ & $0.821^{\star * *}$ & S & $0.483^{\star *}$ \\
\hline $\mathrm{Ni}$ & $0.709^{* * *}$ & $\mathrm{Br}$ & $0.713^{\star * *}$ & $\mathrm{Cu}$ & $0.905^{\star * *}$ & $\mathrm{Ca}$ & $0.372 \mathrm{x}$ & $\mathrm{Zn}$ & $0.573^{\star * *}$ & $\mathrm{Sr}$ & $0.339^{*}$ \\
\hline $\mathrm{V}$ & $0.600^{* * *}$ & Mo & $0.641^{\star * *}$ & Mo & $0.856^{\star \star *}$ & S & $0.321 \mathrm{x}$ & $\mathrm{Fe}$ & $0.467^{\star *}$ & $\mathrm{Fe}$ & $0.336 \mathrm{x}$ \\
\hline $\mathrm{Br}$ & $0.579^{* * *}$ & $\mathrm{Fe}$ & $0.608^{\star * *}$ & $\mathrm{Fe}$ & $0.812^{\star \star \star}$ & As & $0.318 \mathrm{x}$ & $\mathrm{P}$ & $0.437^{\star *}$ & Mn & $0.334 \mathrm{x}$ \\
\hline As & $0.509^{* * *}$ & S & $0.367^{\star}$ & $\mathrm{Ni}$ & $0.779^{\star * *}$ & $\mathrm{Cr}$ & 0.288 & $\mathrm{Mn}$ & $0.331 \mathrm{x}$ & As & $0.323 x$ \\
\hline $\mathrm{Fe}$ & $0.506^{* * *}$ & As & $0.340^{*}$ & V & $0.771^{\star \star \star}$ & $\mathrm{Pb}$ & 0.282 & $\mathrm{Ni}$ & 0.253 & $\mathrm{Zn}$ & $0.280 \mathrm{x}$ \\
\hline Mo & $0.484^{* * *}$ & $\mathrm{Mg}$ & -0.053 & $\mathrm{Cr}$ & $0.767^{\star * *}$ & $\mathrm{Ni}$ & 0.249 & $\mathrm{Cr}$ & 0.222 & $\mathrm{Ni}$ & 0.222 \\
\hline $\mathrm{Ga}$ & 0.144 & $\mathrm{Ba}$ & -0.149 & $\mathrm{Ca}$ & $0.612^{\star * *}$ & $\mathrm{Br}$ & 0.235 & V & 0.084 & $\mathrm{Cr}$ & 0.221 \\
\hline $\mathrm{Ca}$ & 0.118 & $\mathrm{Cu}$ & -0.185 & $\mathrm{Y}$ & $0.525^{\star *}$ & $\mathrm{Cu}$ & 0.229 & $\mathrm{Ti}$ & 0.076 & $\mathrm{P}$ & 0.185 \\
\hline $\mathrm{Cr}$ & 0.088 & $\mathrm{~V}$ & -0.200 & $\mathrm{~Pb}$ & $0.427^{\star}$ & $\mathrm{Ga}$ & 0.226 & $\mathrm{Ca}$ & 0.032 & Mo & 0.135 \\
\hline $\mathrm{Y}$ & -0.057 & $\mathrm{Ni}$ & $-0.240 \mathrm{x}$ & $\mathrm{Ga}$ & 0.163 & $\mathrm{Zn}$ & 0.160 & $\mathrm{Nb}$ & 0.030 & $\mathrm{~V}$ & 0.120 \\
\hline $\mathrm{Mn}$ & -0.063 & $\mathrm{Zn}$ & $-0.373^{\star}$ & $\mathrm{Ba}$ & 0.063 & $\mathrm{Mg}$ & 0.106 & $\mathrm{Cu}$ & -0.040 & $\mathrm{Cu}$ & 0.097 \\
\hline $\mathrm{Al}$ & -0.065 & $\mathrm{P}$ & $-0.445^{\star \star}$ & $\mathrm{Sr}$ & 0.006 & $\mathrm{Al}$ & 0.053 & Mo & -0.065 & $\mathrm{Nb}$ & 0.085 \\
\hline $\mathrm{Nb}$ & -0.086 & $\mathrm{Cr}$ & $-0.517^{\star * *}$ & $\mathrm{Zn}$ & -0.028 & $\mathrm{Rb}$ & 0.027 & $\mathrm{~Pb}$ & -0.082 & $\mathrm{Ti}$ & 0.078 \\
\hline $\mathrm{Sr}$ & -0.121 & $\mathrm{Nb}$ & $-0.577^{\star * *}$ & $\mathrm{Mn}$ & -0.134 & $\mathrm{Y}$ & 0.023 & $\mathrm{Hf}$ & -0.086 & $\mathrm{~Pb}$ & 0.013 \\
\hline $\mathrm{Pb}$ & -0.151 & $\mathrm{Zr}$ & $-0.610^{* * *}$ & $\mathrm{Na}$ & -0.150 & $\mathrm{Ba}$ & -0.072 & $\mathrm{Y}$ & -0.095 & $\mathrm{Ga}$ & 0.008 \\
\hline $\mathrm{Ti}$ & -0.165 & $\mathrm{Ga}$ & $-0.663^{* * *}$ & $\mathrm{P}$ & -0.178 & $\mathrm{P}$ & -0.130 & $\mathrm{Ga}$ & -0.098 & $\mathrm{Rb}$ & -0.032 \\
\hline $\mathrm{Rb}$ & -0.199 & $\mathrm{Ti}$ & $-0.675^{\star * *}$ & $\mathrm{Rb}$ & -0.286 & $\mathrm{Mn}$ & -0.139 & $\mathrm{Rb}$ & -0.174 & $\mathrm{Y}$ & -0.102 \\
\hline $\mathrm{P}$ & $-0.366^{\star}$ & $\mathrm{Hf}$ & $-0.686^{* * *}$ & Hf & -0.301 & $\mathrm{Sr}$ & -0.147 & $\mathrm{Ba}$ & -0.239 & $\mathrm{~K}$ & -0.168 \\
\hline $\mathrm{Hf}$ & $-0.391^{\star *}$ & $\mathrm{~Pb}$ & $-0.697^{* * *}$ & $\mathrm{Al}$ & $-0.325 x$ & $\mathrm{~K}$ & -0.202 & $\mathrm{Al}$ & -0.255 & $\mathrm{Hf}$ & -0.170 \\
\hline K & $-0.449^{\star * *}$ & $\mathrm{Na}$ & $-0.703^{* * *}$ & $\mathrm{~K}$ & $-0.379 x$ & $\mathrm{Nb}$ & -0.203 & $\mathrm{Sr}$ & $-0.320 x$ & $\mathrm{Al}$ & -0.181 \\
\hline $\mathrm{Mg}$ & $-0.457^{\star * *}$ & $\mathrm{Si}$ & $-0.711^{\star * *}$ & $\mathrm{Zr}$ & $-0.403^{\star}$ & $\mathrm{Na}$ & -0.282 & $\mathrm{Zr}$ & $-0.344^{\star}$ & $\mathrm{Mg}$ & -0.214 \\
\hline $\mathrm{Zr}$ & $-0.565^{\star * *}$ & $\mathrm{Al}$ & $-0.780^{* * *}$ & $\mathrm{Mg}$ & $-0.560^{\star *}$ & $\mathrm{Ti}$ & $-0.325 x$ & K & $-0.399^{*}$ & $\mathrm{Ba}$ & -0.247 \\
\hline $\mathrm{Na}$ & $-0.567^{\star * *}$ & $\mathrm{Y}$ & $-0.782^{* * *}$ & $\mathrm{Nb}$ & $-0.611^{\star * *}$ & $\mathrm{Hf}$ & $-0.343 x$ & $\mathrm{Mg}$ & $-0.642^{* * *}$ & $\mathrm{Zr}$ & $-0.479^{\star *}$ \\
\hline $\mathrm{Ba}$ & $-0.573^{\star \star \star}$ & $\mathrm{K}$ & $-0.795^{\star * *}$ & $\mathrm{Ti}$ & $-0.782^{\star \star *}$ & $\mathrm{Zr}$ & $-0.366 x$ & $\mathrm{Na}$ & $-0.662^{\star * *}$ & $\mathrm{Na}$ & $-0.528^{\star * *}$ \\
\hline $\mathrm{Si}$ & $-0.697^{\star * *}$ & $\mathrm{Rb}$ & $-0.805^{\star * *}$ & $\mathrm{Si}$ & $-0.903^{* * *}$ & $\mathrm{Si}$ & $-0.412^{*}$ & $\mathrm{Si}$ & $-0.735^{\star * *}$ & $\mathrm{Si}$ & $-0.645^{\star * *}$ \\
\hline
\end{tabular}

Notes: El - chemical element, $\mathrm{n}$ - number of observations. Sorted Pearson correlation coefficients of chemical element contents: C(TOC) - with TOC, C(TIC) - with TIC. Significance level p of correlation coefficients: $\mathrm{x} \mathrm{p}<0.05,{ }^{\star} \mathrm{p}<0.01,{ }^{* *} \mathrm{p}<0.001$, ${ }_{* * *} \mathrm{p}<0.0001$. 
a

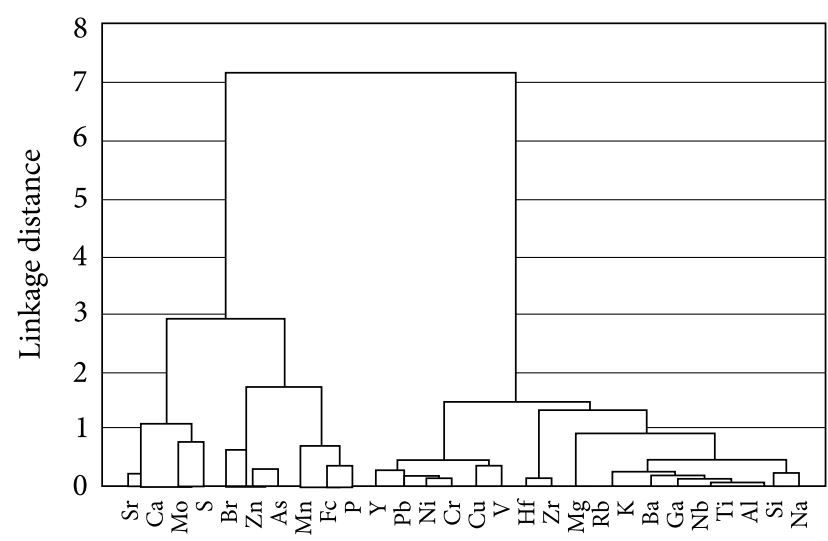

b

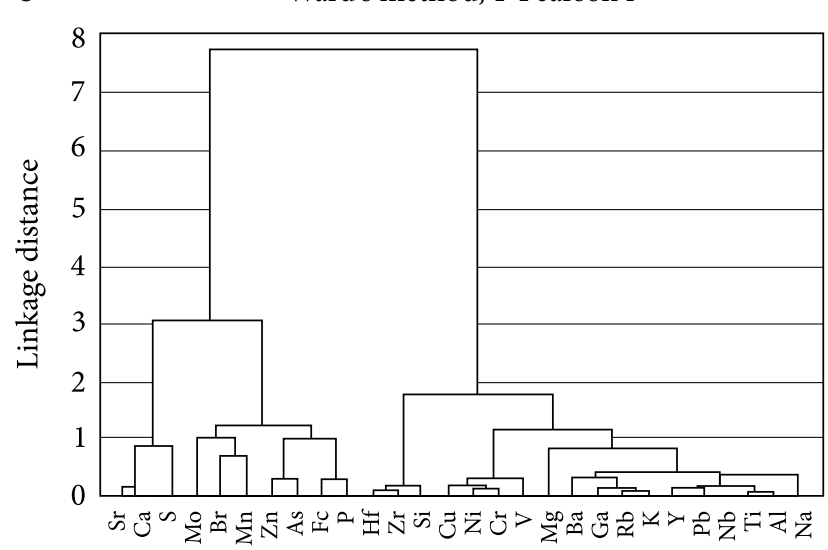

Fig. 7. Dendrograms of anomalous As (a) and anomalous Mo (b) data sets (Fc means Fe)

Such ideally coinciding groups of chemical elements indicate that the sorbents of As and Mo can be the same and that the difference between main sorbents of As and main sorbents of Mo is only relative. Anomalous As $(\mathrm{n}=86)$ has significant positive Pearson correlation coefficients with $\mathrm{Zn}(\mathrm{r}=0.69, \mathrm{p}<0.0001), \mathrm{Br}(\mathrm{r}=0.46, \mathrm{p}<$ 0.0001), Mo $(r=0.40, p<0.001)$, Fe $(r=0.25, p<0.05)$, meanwhile anomalous Mo $(\mathrm{n}=143)$ with As $(\mathrm{r}=0.42, \mathrm{p}<$ $0.0001), \mathrm{Mn}(\mathrm{r}=0.23, \mathrm{p}<0.01), \mathrm{S}(\mathrm{r}=0.19, \mathrm{p}<0.05), \mathrm{Fe}$ $(\mathrm{r}=0.16, \mathrm{p}<0.05)$. Significant correlation between As and Mo in both datasets can be explained by significant correlation of both elements with Fe. In the data set of 170 anomalous samples, where at least one of two elements (As or Mo) exceeds MPC, there are even 59 samples (34.7\%) where both elements have anomalous contents. This fact once again confirms that the reasons for high content of As and Mo are very similar. The above-mentioned eight chemical elements are related to organic, carbonate or other authigenic components of lacustrine sediments. So biogenic and authigenic sedimentation processes were the main reason for As and Mo anomalies.

\section{Discussion}

The fact that part of Quaternary interglacial sediments is enriched in As and Mo adds information to the findings of researchers who emphasise the role of natural sources of contamination and at the same time stimulates further research. Contamination by As from natural sources has been investigated much more compared with Mo.

The geochemical atlas of Europe does not show large-scale anthropogenic contamination by As, but "there are significant areas with naturally occurring high As levels, many of which are above currently used national acceptable guideline values" (Salminen et al. 2005). According to Wang and Mulligan (2006a), the main natural As sources in Cana$\mathrm{da}$ are weathering and erosion of arsenic-containing rocks and soil. Not only volcanic rocks, their weathering products and ash, hydrothermal ore deposits and geothermal waters can be sources of As, but also oceanic sedimentary rocks (e.g. phosphorites) (Baturin 2008), or fossil fuels (e.g. coals) (Yudovich, Ketris 2005). Black shales deposited in stagnant aquatic environments with high organic productivity and oxygen deficiency at the bottom contain especially high As contents (Paikaray 2012).

Natural sources of Mo are known to form (e.g. in pelagic zones of oceanic sediments which contain ferromanganese nodules) (Dubinin et al. 2008). Black shales can be enriched in Mo reaching $70 \mathrm{mg} / \mathrm{kg}$ (Salminen et al. 2005). Coal often has rather high Mo content (Sun et al. 2007).

The causes of As enrichment in sedimentary rocks can be different, because despite solubility of its minerals and compounds, As migration is greatly limited due to its intensive sorption (Reimann et al. 2003). Adsorption and co-precipitation are the main processes controlling As mobility; this element can be sorbed onto different mineral surfaces: clay, oxyhydroxides of $\mathrm{Fe}, \mathrm{Mn}, \mathrm{Al}$ and calcite (Romero et al. 2004), and it can be associated with organic matter (Fu et al. 2013). Such variety of components to which As can be related explains the significant positive correlation of As with both OM and carbonates in interglacial sediments. Besides, our investigation has shown that accumulation of OM and carbonates in interglacial sediments often occurs simultaneously. Higher correlation of As with TOC than with TIC in Netiesos, Šlave and Kudrè-915 sections corresponds to the statement of Reimann et al. (2003) that organic matter may have a marked influence on As concentration and to the findings of Meharg et al. (2006) and Zahid et al. (2009). Besides, high correlation of As with organic matter in these sections corresponds to previous results from Daumantai section (Baltrūnas et al. 2013a) where correlation of As with TOC $(\mathrm{r}=0.21)$ was significant $(\mathrm{n}=156, \mathrm{p}<0.01)$, meanwhile with TIC $(r=0.14)$ it was insignificant. Daumantai section consists of sand but some silt interlayers are enriched in $\mathrm{OM}, \mathrm{S}, \mathrm{Fe}, \mathrm{TIC}$ and $\mathrm{Ca}$. 
Adsorption and co-precipitation processes also control Mo mobility. Molybdenum is well adsorbed by $\mathrm{Fe}, \mathrm{Al}$ and Mn oxyhydroxides (Reimann et al. 2003). Since Mo is a biologically essential element and serves various biochemical functions (Brucker et al. 2011), its significant correlation with organic matter in interglacial sediments is understandable. Correlation of authigenic Mo with TOC has been observed in different objects, e.g. Tanganyika lake sediments (Brucker et al. 2011), marine oil shale from northern Tibet (Fu et al. 2013). Higher correlation of Mo with TIC than with TOC in interglacial sediments can be explained by the fact that molybdate oxyanions are readily co-precipitated not only by $\mathrm{OM}$, but also by $\mathrm{CaCO}_{3}$ and several cations: $\mathrm{Pb}^{2+}, \mathrm{Cu}^{+}, \mathrm{Zn}^{2+}, \mathrm{Mn}^{2+}$ and $\mathrm{Ca}^{2+}$ (Salminen et al. 2005).

Not only interglacial sediments of Lithuania are enriched in As and Mo. Both As and Mo are also among the most enriched trace elements in marine oil shale (Fu et al. 2013). The relationship of As and Mo and their correlation with $\mathrm{Fe}$ in interglacial sediments enables us to presume that their enrichment can be related either to sulphides or to Fe oxyhydroxides, because the experience from Latin America has shown the importance of these minerals for As distribution (Bundschuh et al. 2012). According to Paikaray (2012) who studied black shales, iron sulphidization occurs in relatively deeper depositional environments. These conditions favour a stagnant euxinic layer for OM deposition, besides, lack of clastic dilution enhances OM deposition. Microbial sulphate reduction to hydrogen sulphide and subsequent precipitation as metal sulphides takes place there (Paikaray 2012). Fu et al. (2013) explained As and Mo anomalies in marine oil shale by sulphide minerals and organic matter. Arsenic in coal is also either in sulphides or in organic compounds, both being authigenic (Yudovich, Ketris 2005). However, since correlation of As with $S$ in anomalous interglacial sediments is not significant, the second presumption about relationship of As and Mo with Fe oxyhydroxides seems to us more reasonable. The relationship of As with Fe oxides and hydroxides has been proven by SEM image analysis of some stream sediments from Greece (Alexakis 2011). Increased contents of $\mathrm{Fe}, \mathrm{Mn}, \mathrm{Mo}$ and $\mathrm{P}$ were observed in $\mathrm{FeOOH}_{\mathrm{x}}$ layers; the explanation was that $\mathrm{Fe}$ and Mn oxides strongly absorb oxyanions such as phosphate, arsenate and molybdate (Zahid et al. 2009).

The possibility of As and Mo release from interglacial sediments is still not estimated. About $18 \%$ of the total content of As and Mo may not be extracted from soil even by aqua regia, because their median degree of extractability in aqua regia from some European soil samples analysed by ISE participants is only $82 \%$ (Taraškevičius et al. 2013). In agricultural soils of 10 European countries the respective index for As is even lower: from $28 \%$ in Russia to $77 \%$ in Lithuania and Poland (Reimann et al. 2003).

On the other hand, obvious release of As from Holocene aquifers to groundwater where As concentration reached toxic levels has been observed in 61 of 64 districts of Bangladesh (Zahid et al. 2009). Groundwater in Bangladesh when used for irrigation of rice paddies also causes problems, though the exposure of population to As in rice is of less concern compared to As in untreated groundwater (Van Geen et al. 2006).

Release of As to ground- and surface water greatly depends on $\mathrm{pH}$, redox potential, contents of OM, ions present and ionic strength (Bundschuh et al. 2012). Natural organic matter not only reduces, but often enhances, As mobility (Wang, Mulligan 2006b). According to Bundschuh et al. (2012), remobilisation of As from metal oxides and oxyhydroxides can be either by their dissolution under very acid conditions or by desorption of As from them at high $\mathrm{pH}(>8)$ and oxidising conditions. The mechanisms of As release from black shales have been investigated by Paikaray (2012); the conclusion was that in suitable geochemical conditions these deposits can be important source of As in the environment.

\section{Conclusions}

1. Interglacial sediments, especially enriched in organic matter, carbonates and other sorbents, comprise one of the possible natural sources of As and Mo anomalies in stream sediments of Lithuania.

2. Biogenic and authigenic sedimentation processes often take place simultaneously and were the main reason for As and Mo anomalies.

3. Anomalous contents of As and Mo correlate with the content of $\mathrm{Fe}$, indicating iron minerals as probable sources and sinks. Anomalies of As are related to organic matter and partly to carbonates. Mo is more related to carbonates than to organic matter.

\section{Acknowledgements}

The authors are grateful to the Research Council of Lithuania for financial support (project registration No LEK12007).

\section{References}

Alexakis, D. 2011. Diagnosis of stream sediment quality and assessment of toxic element contamination sources in East Attica, Greece, Environmental Earth Sciences 63(6): 1369-1383. http://dx.doi.org/10.1007/s12665-010-0807-9

Ayris, P. M.; Delmelle, P. 2012. The immediate environmental effects of tephra emission, Bulletin of Volcanology 74(9): 1905-1936. http://dx.doi.org/10.1007/s00445-012-0654-5

Baba, A.; Tayfur, G. 2011. Groundwater contamination and its effect on health in Turkey, Environmental Monitoring and Assessment 183(1-4): 77-94.

http://dx.doi.org/10.1007/s10661-011-1907-z 
Baltrūnas, V.; Gaigalas, A. 2004. Entropy of Pleistocene till composition as an indicator of sedimentation conditions in southern Lithuania [online], [cited 17 April 2014], Geological Quarterly 48(2): 115-122. Available from Internet: https:// gq.pgi.gov.pl/article/view/7337

Baltrūnas, V.; Zinkutè, R.; Šeirienè, V.; Katinas, V.; Karmaza, B.; Kisielienė, D.; Taraškevičius, R.; Lagunavičiene, L. 2013a. Sedimentary environment changes during the Early-Middle Pleistocene transition as recorded by the Daumantai sections in Lithuania, Geological Quarterly 57(1): 45-59. http://dx.doi.org/10.7306/gq.1076

Baltrūnas, V.; Zinkute, R.; Taraškevičius, R.; Karmaza, B.; Šeirienè, V.; Kisielienè, D. 2013b. Interglacial Quaternary sediments as possible natural source of anomalies of harmful chemical elements in Lithuania, E3S Web of Conferences 1: 16010. http://dx.doi.org/10.1051/e3sconf/20130116010

Baltrūnas, V.; Šeirienė, V.; Molodkov, A.; Zinkutė, R.; Katinas, V.; Karmaza, B.; Kisielienė, D.; Petrošius, R.; Taraškevičius, R.; Piličiauskas, G.; Schmolcke, U.; Heinrich, D. 2013c. Depositional environment and climate changes during the late Pleistocene as recorded by the Netiesos section in southern Lithuania, Quaternary International 292: 136-149. http://dx.doi.org/10.1016/j.quaint.2012.11.038

Baturin, G. N. 2008. Arsenic, antimony, and bismuth in oceanic phosphorites, Doklady Earth Sciences 419(2): 266-269. http://dx.doi.org/10.1134/S1028334X08020177

Ber, A. 2006. Pleistocene interglacials and glaciations of northeastern Poland compared to neighbouring areas, Quaternary International 149(1): 12-23. http://dx.doi.org/10.1016/j.quaint.2005.11.014

Brucker, R. P.; McManus, J.; Severmann, S; Owens, J.; Lyons, T. W. 2011. Trace element enrichments in Lake Tanganyika sediments: controls on trace metal burial in lacustrine systems, Geochimica et Cosmochimica Acta 75(2): 483-499. http://dx.doi.org/10.1016/j.gca.2010.09.041

Bundschuh, J.; Litter, M. I.; Parvez, F.; Román-Ross, G.; Nicolli, H. B.; Jean, J.-S.; Liu, C.-W.; López, D.; Armienta, M. A.; Guilherme, L. R. G.; Gomez Cuevas, A.; Cornejo, L.; Cumbal, L.; Toujaguez, R. 2012. One century of arsenic exposure in Latin America: a review of history and occurrence from 14 countries, Science of The Total Environment 429: 2-35. http://dx.doi.org/10.1016/j.scitotenv.2011.06.024

Butkus, D.; Šalciūniene, K. 2011. Investigation of heavy metal and radionuclide distribution in silt of Lake Didžiulis, Journal of Environmental Engineering and Landscape Management 19(3): 215-224. http://dx.doi.org/10.3846/16486897.2011.602554

Calvo, A. I.; Alves, C.; Castro, A.; Pont, V.; Vicente, A. M.; Fraile, R. 2013. Research on aerosol sources and chemical composition: past, current and emerging issues, Atmospheric Research 120-121: 1-28. http://dx.doi.org/10.1016/j.atmosres.2012.09.021

Dubinin, A. V.; Sval'nov, V. N.; Uspenskaya, T. Yu. 2008. Geochemistry of the authigenic ferromanganese ore formation in sediments of the Northeast Pacific Basin, Lithology and Mineral Resources 43(2): 99-110.

http://dx.doi.org/10.1134/S0024490208020016

Ernst, W. G. 2012. Overview of naturally occurring Earth materials and human health concerns, Journal of Asian Earth Sciences 59: 108-126.

http://dx.doi.org/10.1016/j.jseaes.2012.05.030
Falk, H.; Lavergren, U.; Bergbäck, B. 2006. Metal mobility in alum shale from Öland, Sweden, Journal of Geochemical Exploration 90(3): 157-165. http://dx.doi.org/10.1144/1467-7873/08-188

Fu, X.; Wang, J.; Zeng, Y.; Tan, F.; Feng, X. 2013. Trace elements and their behaviour during the combustion of marine oil shale from Changliang Mountain, northern Tibet, China, Environmental Earth Sciences 70: 1125-1134. http://dx.doi.org/10.1007/s12665-012-2199-5

Galkus, A.; Stakenienė, R.; Jokšas, K.; Lagunavičienė, L. 2012. Assessing bottom sediment contamination with heavy metals in the Klaipeda port semi-closed bays, Journal of Environmental Engineering and Landscape Management 20(4): 307-315. http://dx.doi.org/10.3846/16486897.2012.660883

Gudas, M.; Povilaitis, A. 2013. Factors affecting seasonal and spatial patterns of water quality in Lithuanian rivers, Journal of Environmental Engineering and Landscape Management 21(1): 26-35.

http://dx.doi.org/10.3846/16486897.2012.696058

Idzelis, R. L.; Greičiūte, K.; Paliulis, D. 2006. Investigation and evaluation of surface water pollution with heavy metals and oil products in Kairiai military ground territory, Journal of Environmental Engineering and Landscape Management 14(4): 183-190. http://dx.doi.org/10.1080/16486897.2006.9636896

Ignatavičius, G.; Sakalauskienè, G; Oškinis, V. 2006. Influence of land fires on increase of heavy metal concentrations in river waters of Lithuania, Journal of Environmental Engineering and Landscape Management 14(1): 46-51. http://dx.doi.org/10.1080/16486897.2006.9636878

Jaskelevičius, B.; Lynikiené, V. 2009. Investigation of influence of Lapes landfill leachate on ground and surface water pollution with heavy metals, Journal of Environmental Engineering and Landscape Management 17(3): 131-139. http://dx.doi.org/10.3846/1648-6897.2009.17.131-139

Kadūnas, V.; Budavičius, R.; Gregorauskienė, V.; Katinas, V.; Kliaugienè, E.; Radzevičius, A.; Taraškevičius, R. 1999. Lietuvos geocheminis atlasas [Geochemical Atlas of Lithuania]. Vilnius (in Lithuanian and English).

Kondratiene, O. 1996. Stratigrafija i paleogeografija kvartera Litvy po paleobotanicheskim dannym [Stratigraphy and paleogeography of Quaternary in Lithuania according to palaeobotanic data]. Academia, Vilnius (in Russian, with English summary).

Kumpienè, J.; Brännvall, E.; Taraškevičius, R.; Aksamitauskas, Č.; Zinkute, R. 2011. Spatial variability of topsoil contamination with trace elements in preschools in Vilnius, Lithuania, Journal of Geochemical Exploration 108(1): 15-20. http://dx.doi.org/10.1016/j.gexplo.2010.08.003

Lachmar, T. E.; Burk, N. I.; Kolesar, P. T. 2006. Groundwater contribution of metals from an abandoned mine to the north fork of the American Fork River, Utah, Water, Air, and Soil Pollution 173: 103-120. http://dx.doi.org/10.1007/s11270-005-9031-8

Lindner, L.; Gozhik, P.; Marciniak, B.; Marks, L.; Yelovicheva, Y. 2004. Main climatic changes in the Quaternary of Poland, Belarus and Ukraine [online], [cited 17 April 2014], Geological Quarterly 48(2): 97-114. Available from Internet: https:// gq.pgi.gov.pl/article/view/7336

Lindner, L.; Bogutsky, A.; Gozhik, P.; Marks, L.; Łanczont, M.; Wojtanowicz, J. 2006. Correlation of Pleistocene deposits in the area between the Baltic and Black Sea, Central Europe 
[online], [cited April 17, 2014], Geological Quarterly 50(1): 195-210. Available from Internet: https://gq.pgi.gov.pl/article/view/7405

Lindner, L.; Marks, L.; Nita, M. 2013. Climatostratigraphy of interglacials in Poland: Middle and Upper Pleistocene lower boundaries from Polish perspective, Quaternary International 292: 113-123. http://dx.doi.org/10.1016/j.quaint.2012.11.018

Marozas, V.; Armolaitis, K.; Aleinikoviene, J. 2013. Changes of ground vegetation, soil chemical properties and microbiota following the surface fires in Scots pine forests, Journal of Environmental Engineering and Landscape Management 21(1): 67-75. http://dx.doi.org/10.3846/16486897.2012.663087

Meharg, A. A.; Scrimgeour, C.; Hossain, S. A.; Fuller, K.; Cruickshank, K.; Williams, P. N., et al. 2006. Codeposition of organic carbon and arsenic in Bengal Delta aquifers, Environmental Science and Technology 40: 4928-4935. http://dx.doi.org/10.1021/es060722b

Milukaitè, A.; Valiulis, D.; Šakalys, J. 2008. Fluxes and loading of heavy metals, benzo[a]pyrene and oil products in Vilnius City, Water, Air and Soil Pollution: Focus 8: 485-494. http://dx.doi.org/10.1007/s11267-008-9181-y

Nagajyoti, P. C.; Lee, K. D.; Sreekanth, T. V. M. 2010. Heavy metals, occurrence and toxicity for plants: a review, Environmental Chemistry Letters 8: 199-216. http://dx.doi.org/10.1007/s10311-010-0297-8

Paikaray, S. 2012. Environmental hazards of arsenic associated with black shales: a review on geochemistry, enrichment and leaching mechanism, Reviews in Environmental Science and Biotechnology 11: 289-303.

http://dx.doi.org/10.1007/s11157-012-9281-z

Pereira, P.; Ubeda, X. 2010. Spatial distribution of heavy metals released from ashes after a wildfire, Journal of Environmental Engineering and Landscape Management 18(1): 13-22. http://dx.doi.org/10.3846/jeelm.2010.02

Pundytè, N.; Baltrènaite, E.; Pereira, P.; Paliulis, D. 2011. Anthropogenic effects on heavy metals and macronutrients accumulation in soil and wood of Pinus sylvestris L., Journal of Environmental Engineering and Landscape Management 11(1): 34-43. http://dx.doi.org/10.3846/16486897.2011.557473

Reimann, C.; Siewers, U.; Tarvainen, T.; Bityukova, L.; Eriksson, J.; Gilucis, A.; Gregorauskiene, V.; Lukashev, V. K.; Matinian, N. N.; Pasieczna, A. 2003. Agricultural soils in Northern Europe: A Geochemical Atlas. E. Schweizerbart'sche Verlagsbuchhandlung, Stuttgart.

Romero, F. M.; Armienta, M. A.; Carrillo-Chavez, A. 2004. Arsenic sorption by carbonate-rich aquifer material, a control on arsenic mobility at Zimapán, México, Archives of Environmental Contamination and Toxicology 47(1): 1-13. http://dx.doi.org/10.1007/s00244-004-3009-1

Salminen, R.; Plant, J.; Reeder, S. (Eds.) 2005. Geochemical Atlas of Europe. Part 1, Background information, methodology and maps. Espoo, Finland, Geological Survey of Finland.

Santisteban, J. I.; Mediavilla, R.; López-Pamo, E.; Dabrio, C. J.; Ruiz Zapata, M. B.; Gil Garcia, M. J.; Castano, S.; MartinezAlfaro, P. E. 2004. Loss on ignition: a qualitative or quantitative method for organic matter and carbonate mineral content in sediments?, Journal of Paleolimnology 32(3): 287-299. http://dx.doi.org/10.1023/B:JOPL.0000042999.30131.5b

Sun, Y.; Lin, M.; Qin, P.; Zhao, C.; Jin, K. 2007. Geochemistry of the barkinite liptobiolith (Late Permian) from the Jinshan mine, Anhui Province, China, Environmental Geochemistry and Health 29: 33-44.

http://dx.doi.org/10.1007/s10653-006-9059-8

Stakenienè, R.; Galkus, A.; Jokšas, K. 2011. Pollution of Klaipeda Port waters [online], [cited 17 April 2014], Polish Journal of Environmental Studies 20(2): 445-459. Available from Internet: http://www.pjoes.com/pdf/20.2/Pol.J.Environ.Stud. Vol.20.No.2.445-459.pdf

Taraškevičius, R.; Zinkutè, R. 2011. Lietuvos miestų geocheminès anomalijos ir jų sklaida [Urban geochemical anomalies of Lithuania and their spread] [online], [cited 17 April 2014], Baltica 24, Special Issue "Geosciences in Lithuania: challenges and perspectives": 163-168 (in Lithuanian). Available from Internet: http://www.geo.lt/geo/index.php?id=1375

Taraškevičius, R.; Zinkute, R.; Stakenienè, R.; Radavičius, M. 2013. Case study of relationship between aqua regia and real total contents of harmful trace elements in some European soils, Journal of Chemistry 2013(2013): 15. http://dx.doi.org/10.1155/2013/678140

Van Geen, A.; Zheng, Y.; Cheng, Z.; He, Y.; Dhar, R. K.; Garnier, J. M.; Rose, J.; Seddique, A.; Hoque, M. A.; Ahmed, K. M. 2006. Impact of irrigating rice paddies with groundwater containing arsenic in Bangladesh, Science of The Total Environment 367(2-3): 769-777. http://dx.doi.org/10.1016/j.scitotenv.2006.01.030

Vasarevičius, S.; Greičiūte, K. 2004. Investigation of soil pollution with heavy metals in Lithuanian military grounds, Journal of Environmental Engineering and Landscape Management 12(4): 132-137. http://dx.doi.org/10.1080/16486897.2004.9636834

Vasarevičius, S.; Mineikaitè, A.; Vaitiekūnas, P. 2010. Investigation into heavy metals in storm wastewater from Vilnius Žirmūnai District and pollutants spread model in Neris River, Journal of Environmental Engineering and Landscape Management 18(3): 242-249. http://dx.doi.org/10.3846/jeelm.2010.28

Von der Heyden, C. J.; New, M. G. 2004. Groundwater pollution on the Zambian Copperbelt: deciphering the source and the risk, Science of The Total Environment 327(1-3): 17-30. http://dx.doi.org/10.1016/j.scitotenv.2003.08.028

Wang, S.; Mulligan, C. N. 2006a. Occurrence of arsenic contamination in Canada: Sources, behaviour and distribution, Science of The Total Environment 366: 701-721. http://dx.doi.org/10.1016/j.scitotenv.2005.09.005

Wang, S.; Mulligan, C. N. 2006b. Effect of natural organic matter on arsenic release from soils and sediments into groundwater, Environmental Geochemistry and Health 28: 197-214. http://dx.doi.org/10.1007/s10653-005-9032-y

Yudovich, Ya. E.; Ketris, M. P. 2005. Arsenic in coal: a review, International Journal of Coal Geology 61(3-4): 141-196. http://dx.doi.org/10.1016/j.coal.2004.09.003

Zahid, A.; Hassan, M. Q.; Breit, G. N.; Balke, K.-D.; Flegr, M. 2009. Accumulation of iron and arsenic in the Chandina alluvium of the lower delta plain, Southeastern Bangladesh, Environmental Geochemistry and Health 31: 69-84. http://dx.doi.org/10.1007/s10653-008-9226-1

Zinkutè, R.; Taraškevičius, R.; Želvys, T. 2011. Major elements as possible factors of trace element urban pedochemical anomalies, Central European Journal of Chemistry 9(2): 337-347. http://dx.doi.org/10.2478/s11532-011-0012-z 
Rimantė ZINKUTE். Senior Researcher at the Nature Research Centre Institute of Geology and Geography. Doctor of Physical (Geology) Sciences (Vilnius University and Institute of Geology, 1998). In 1998-2013 published 52 scientific articles and one monograph. Co-author of two atlases and two monographs. Scientific interests: major and trace elements in contemporary and Quaternary sediments, geochemical associations, assessment of contamination, application of mathematical-statistical methods for treatment of geochemical data.

Valentinas BALTRŪNAS. Head of the project at the Nature Research Centre Institute of Geology and Geography. Dr Habil. of Physical (Geology) Sciences (Vilnius University and Institute of Geology, 1998), Professor of Lithuanian University of Educational Sciences. In 1998-2013 published 74 scientific articles and monographs. Scientific interests: sedimentology (glacial and interglacial formations of the Pleistocene), environmental geology, methodology of environmental research.

Ričardas TARAŠKEVIČIUS. Head of Geochemistry Division and Senior Researcher at Nature Research Centre Institute of Geology and Geography. Doctor of Physical (Geochemistry) Sciences (Institute of Geochemistry and Geophysics, Minsk, 1992). Co-author of two atlases, three monographs and over 70 scientific articles. Scientific interests: analytical methods, quality control, geochemical anomalies, their determinant factors, reflection and influence on biota, health effects, ecogeochemical evaluation, visualization and mathematical processing of geochemical data.

Bronislavas KARMAZA. Senior Researcher at the Nature Research Centre Institute of Geology and Geography. Doctor of Physical (Geology) Sciences (Vilnius University and Institute of Geology, 1995). Scientific interests: Lithuanian Pleistocene glaciolacustrine, glaciofluvial sediments, their structure and composition, geological heritage, application of distant methods for the research of Quaternary sediments, archaeological camps and settlements. Author/co-author of over 30 scientific articles. Research interests: geochemistry, land degradation, soil pollution.

Rimutė STAKĖNIENĖ. Researcher at the Nature Research Centre Institute of Geology and Geography. Doctor of Physical (Geography) Sciences (Vilnius University and Institute of Geography, 1999). Author and co-author of over 40 scientific papers and one monograph. Scientific interests: organic geochemistry of sediments and water column; environmental pollution and its reduction.

Vaida ŠEIRIENĖ. Head of Quaternary Research Laboratory and Senior Researcher at the Nature Research Centre Institute of Geology and Geography. Doctor of Physical (Geology) Sciences (Vilnius University and Institute of Geology, 1996). Author and co-author of over 50 scientific papers and five monographs. Scientific interests: Quaternary stratigraphy and geology, diatom flora, interglacial palaeoecology and palaeogeography.

Dalia KISIELIENĖ. Senior researcher at Nature Research Centre Institute of Geology and Geography. Doctor of Physical (Geology) Sciences (Vilnius University and Institute of Geology and Geography, 2002). Author and co-author of more than 30 scientific papers and five monographs. Scientific interests: Quaternary stratigraphy and geology, palaeobotany, palaeoecology and palaeogeography, human impact on palaeoecosystems. 